\title{
BOTRYOID CYST, A RARE TYPE OF ODONTOGENIC CYST
}

\author{
Bruno Vidaković ${ }^{1}$, Ivana Uljanić ${ }^{2}$ Jakša Grgurević ${ }^{2}$, Berislav Perić ${ }^{2}$ and Spomenka Manojlović ${ }^{3}$ \\ ${ }^{1}$ Dr. Josip Benčević General Hospital, Department of ENT and Head and Neck Surgery, Slavonski Brod; \\ ${ }^{2}$ University of Zagreb, School of Dental Medicine, Department of Oral Surgery; ${ }^{3}$ University of Zagreb, \\ School of Medicine, Department of Clinical and Experimental Pathology, Zagreb, Croatia
}

\begin{abstract}
SUMMARY - Botryoid cyst, a rare type of odontogenic cyst, is usually considered a multilocular variant of lateral periodontal cyst. It was first described in 1973, and up to the present less than a hundred cases have been reported in the literature. Botryoid cysts are characterized by a multilocular histologic finding and a higher risk of recurrence than lateral periodontal cysts. In this article, we present a case of botryoid cyst from our clinical practice, accompanied by literature review of previous cases reported in the literature so far. Study results showed that botryoid cysts mostly affected population in their fifties, with a slight female (53.5\%) predominance over males (46.5\%). The mandible was the most frequently affected region, accounting for 70 (83.3\%) cases. Maxilla was only sporadically affected accounting for 14 (16.7\%) cases. Radiographic appearance of botryoid cysts can be multilocular or unilocular. It is concluded that the recurrence rate is relatively high (30.1\%), therefore long term follow up is needed.
\end{abstract}

Key words: Odontogenic cysts - diagnosis; Odontogenic cysts - pathology; Diagnosis, differential; Mandibular diseases - diagnosis; Mandibular diseases - pathology; Case reports

\section{Introduction}

Botryoid odontogenic cyst (BOC) was first described in 1973 by Weathers and Waldron and it is usually described in the literature as a multicystic variant of lateral periodontal cyst (LPC) ${ }^{1}$. On the other hand, other authors such as Van der Waal considered BOC as a different clinical entity in relation to LPC, and suggested that $\mathrm{BOC}$ was a multicystic lesion with increased growth potential with similar histologic features to $\mathrm{LPC}^{2}$. The etiology and histogenesis of BOC remains uncertain, and several proposed possible sources such as epithelial cell rests of Malassez and reduced enamel epithelium have been rejected as the possible sources ${ }^{3}$. Remnants of dental lamina could be

Correspondence to: Bruno Vidakovic, DMD, $P h D$, Department of ENT and Head and Neck Surgery, Dr. Josip Benčević General Hospital, Andrije Štampara 42, HR-35000 Slavonski Brod, Croatia

E-mail: brunovidakovic@yahoo.com

Received December 23, 2014, accepted June 2, 2015 the basis from which BOC arises because of histologic similarities between dental lamina and the cyst wall, which is characterized by the presence of glycogen rich clear cells that are found both in dental lamina and in the cyst wall ${ }^{4}$. The name BOC is derived from the Greek word botrys, which means a cluster of grapes because of its multilocular histologic appearance ${ }^{5}$. In comparison to $\mathrm{LPC}, \mathrm{BOC}$ tends to be larger in size than LPC, probably due to the increased growth potential. Radiological finding is somewhat different ranging from unilocular to multilocular appearance. The major difference between the two entities is a much higher rate of recurrence in BOC. However, the reasons of the higher recurrence rate are still unknown ${ }^{3,6,7}$. According to the literature, BOCs are often characterized by the absence of symptoms, and in cases when the symptoms are present they are nonspecific and accompanied by the same nonspecific clinical appearance. BOC usually affects adults in their fifties and older, although cases of BOC are also noted in 
Fig. 1. Panoramic radiograph: radiolucency extending distally from tooth 35 to the ramus of the mandible.

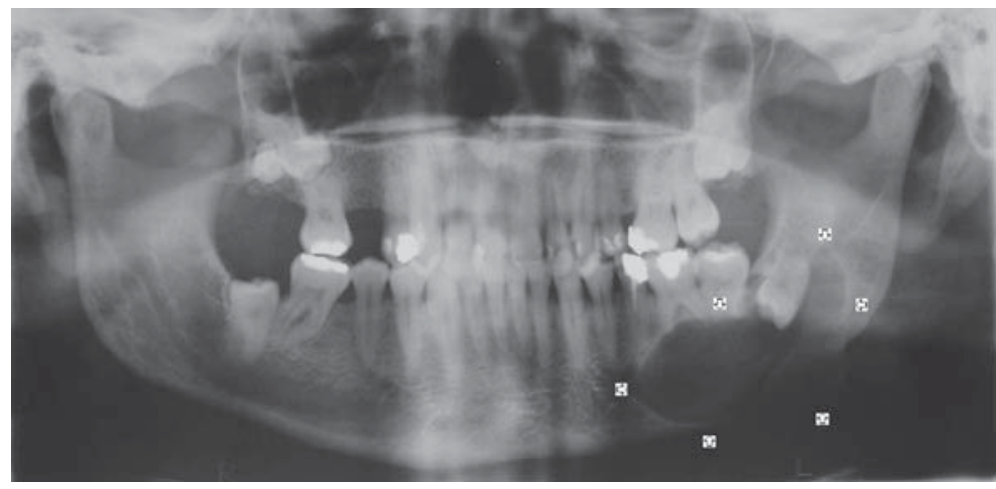

younger population ${ }^{2,8,9}$. LPC and BOC are rather uncommon. LPCs were described in $1958^{10}$. Since then, more than 270 cases have been documented, and it is assumed that LPCs account for $0.8 \%$ of all jaw cysts $^{11-14}$. BOCs are even more uncommon and in the past four decades, since 1973, when the first case of BOC was described, less than one hundred cases of this rare type of odontogenic cyst have been reported in the literature. In this article, we describe our case of $\mathrm{BOC}$ and a review of 87 cases of BOC reported in the literature since the first case up to the present.

\section{Case Report}

In May 2013, a 44-year-old man was referred to the Department of Oral Surgery, Clinical Department of Maxillofacial and Oral Surgery because of occasional pain in the left lower jaw, which was mainly present during mastication. Clinical examination and palpation revealed mobility of the first and second left lower molars, with minor swelling in the lower left buccal vestibule. Panoramic radiograph was performed to show a well delimited unilocular radiolucency located in the left body of the mandible, extending distally from the tooth 35 to the ramus of the mandible (Fig. 1). Surgical removal of the cyst was offered to the patient. After obtaining his informed consent, under general anesthesia, mucoperiosteal incision was performed; movable teeth 36,37 and impacted tooth 38 were removed. The cyst was enucleated with some difficulty, especially in the lower part along the alveolar nerve. The continuity of the alveolar nerve was preserved. Surgically removed specimens were sent for histologic analysis which revealed a cystic lesion traversed by fibrous septa. Microscopically, cystic spaces

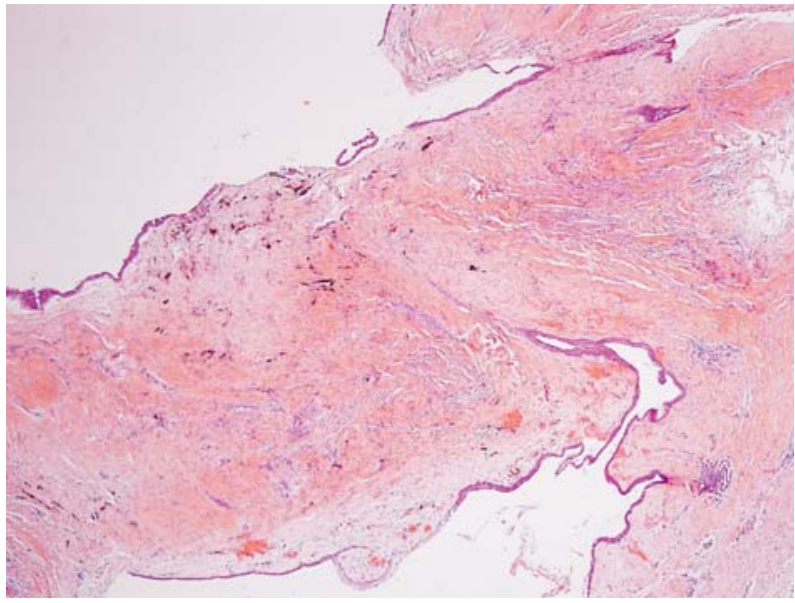

Fig. 2. Several cystic spaces bordered by a thin layer of cuboid odontogenic epithelium. (HE, X 40)

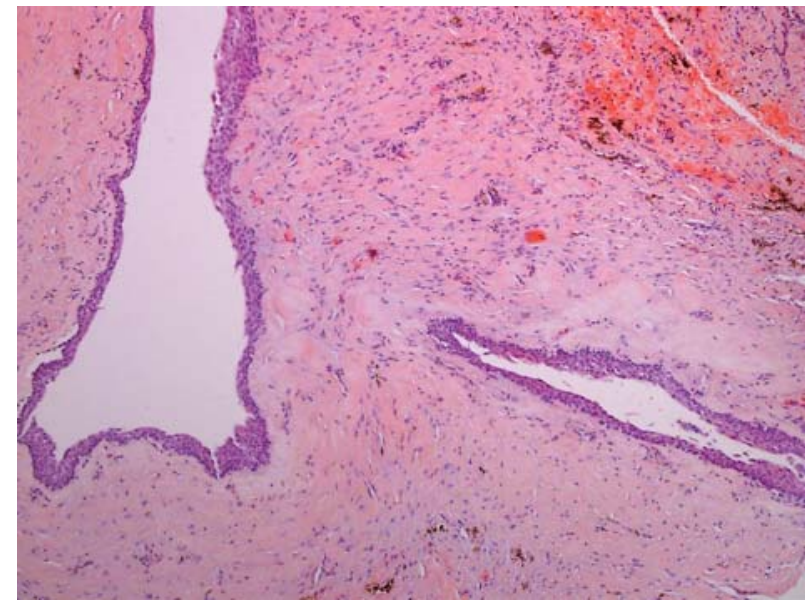

Fig. 3. Cuboid cells resembling reduced enamel epithelium cover the hyalinized fibrous septa. (HE, X100)

were composed of connective fibrous tissue devoid of inflammatory infiltrate and covered by a thin layer of odontogenic epithelium (Fig. 2). Subepithelial fibrous 

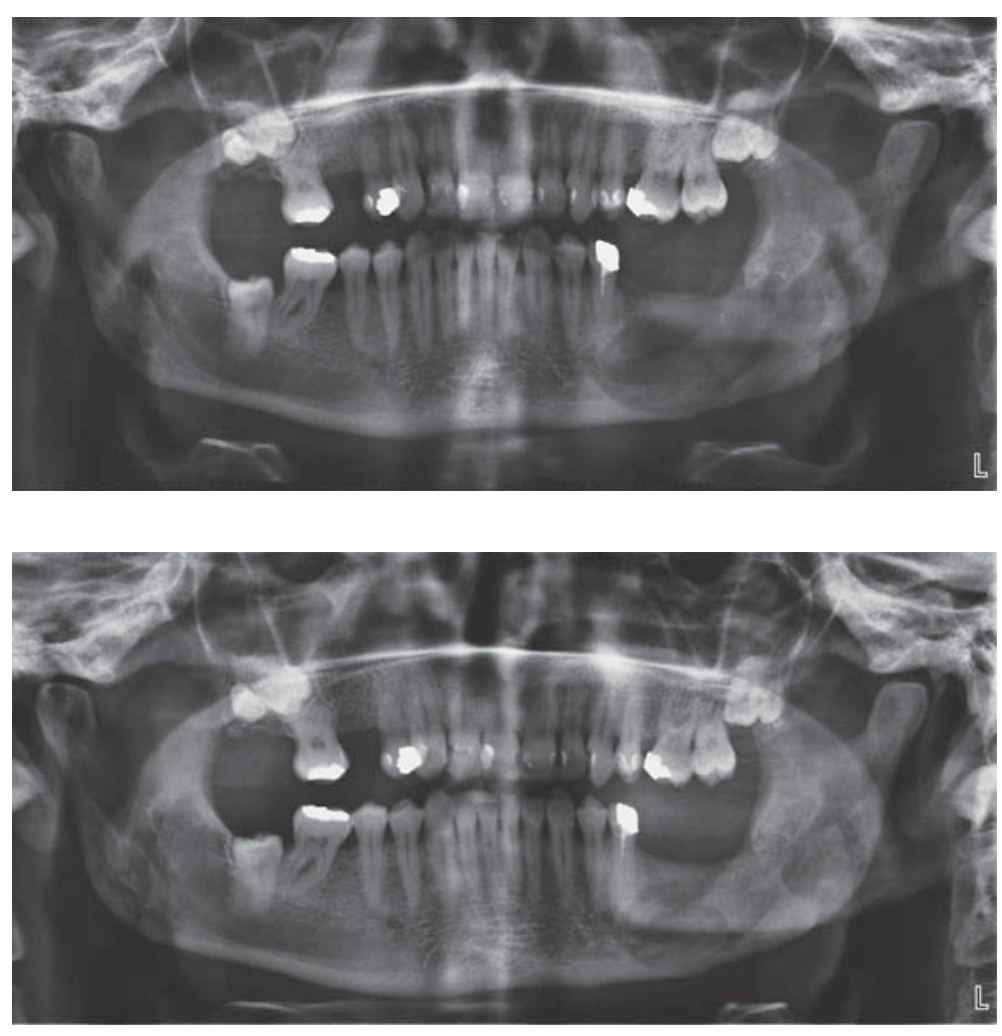

Fig. 4. Panoramic radiograph

3 months after surgery.

Fig. 5. Panoramic radiograph

1 year after surgery. tissue revealed a zone of hyalinization (Fig. 3). Definitive diagnosis was BOC. Panoramic radiographs were performed 3 months (Fig. 4) and 1 year (Fig. 5) after surgery showing a normal postoperative finding. One year after the surgery, the alveolar nerve function was normal.

\section{Discussion}

Botryoid odontogenic cyst is an unusual and rare type of odontogenic cyst. Analysis of 88 BOC cases showed that patient age ranged from 20 to 80 , mean age 50.2 years (Table 1). According to data on the reviewed cases available, 46 (53.5\%) BOC cases occurred in female patients and 40 (46.5\%) BOC cases in male patients; the fractional female predisposition was in accordance with previous studies ${ }^{15}$. The mandible was most frequently affected by BOC, accounting for 70 (83.3\%) cases, whereas maxilla was only sporadically affected with 14 (16.7\%) cases, and 4 non specified cases. According to the literature, histologic features of $\mathrm{BOC}$ are multilocular histologic appearance, presence of microcysts, and thin squamous epithelium with focal plaque-like thickenings, subepithelial hyaliniza- tion, and clear cells. Histologic patterns of BOC and LPC are similar yet still presenting a controversial topic. Multilocular histologic appearance distinguishes BOC from LPC. In addition, BOCs are generally larger than LPC and because of that it can be assumed that these distinctive features of BOC add to its more expansive character, making surgical removal more difficult ${ }^{6,16-19}$. From our experience of the relatively large $\mathrm{BOC}$, we can confirm that enucleation of BOC was rather difficult. In the literature, $\mathrm{BOCs}$ are reported as a type of odontogenic cyst with a relatively high recurrence rate. Mendez et al. report on the BOC recurrence rate of $32.4 \%{ }^{14}$. In our analysis, follow up was reported in 53 cases of all analyzed cases, whereas recurrences were reported in $16(30.1 \%)$ cases, yielding a slightly lower rate than that reported by Mendez et al., but still relatively high. The relatively high recurrence rate may be due to the multilocular histologic pattern, which contributes to enucleation difficulty, and the possibly greater $\mathrm{BOC}$ growth potential in comparison with LPC.

In this study, radiographic data were available for 64 cases. There was a slight predominance of unilocular radiolucencies since unilocular radiolucencies were 
Table 1. Literature review of 87 botryoid odontogenic cyst cases

\begin{tabular}{|c|c|c|c|c|c|c|c|}
\hline Authors/year & \begin{tabular}{|l|} 
Sex \\
$(\mathrm{M} / \mathrm{F})$
\end{tabular} & $\begin{array}{l}\text { Median } \\
\text { age (yrs) }\end{array}$ & \begin{tabular}{|l}
$\begin{array}{l}\text { Number } \\
\text { of cases }\end{array}$ \\
\end{tabular} & Localization & $\begin{array}{l}\text { Radiographic } \\
\text { appearance }\end{array}$ & Follow up & Recurrence \\
\hline Lynch and Madden/1985 & $\mathrm{F}$ & 36 & 1 & Premolar/N/A & N/A & N/A & N/A \\
\hline Barone et al./1990 & N/A & N/A & 2 & N/A & N/A & N/A & N/A \\
\hline Van der Waal/1992 & $\mathrm{F}$ & 23 & 1 & Mandible & N/A & N/A & N/A \\
\hline Falcone et al./1995 & $\mathrm{F}$ & 55 & 1 & Mandible & N/A & N/A & N/A \\
\hline Weibrich et al./2000 & $\mathrm{M}$ & 64 & 1 & Mandible & Multilocular & N/A & N/A \\
\hline Chi et al./2007 & $\mathrm{F}$ & 80 & 1 & Mandible & Multilocular & N/A & N/A \\
\hline Mendez et al./2007 & $\begin{array}{l}34 \mathrm{~F} \\
28 \mathrm{M}\end{array}$ & 53.8 & 62 & $\begin{array}{l}52 \text { mandible } \\
9 \text { maxilla } \\
1 \text { N/A } \\
\end{array}$ & $\begin{array}{l}18 \text { Multilocular } \\
27 \text { unilocular } \\
17 \text { N/A }\end{array}$ & $\begin{array}{l}37 \text { yes } \\
25 \text { no }\end{array}$ & $\begin{array}{l}12 \text { yes } \\
25 \mathrm{no} \\
25 \mathrm{~N} / \mathrm{A}\end{array}$ \\
\hline Chbicheb et al./2008 & $\mathrm{F}$ & 23 & 1 & Maxilla & Multilocular & Yes & No \\
\hline Hethcox et al./2010 & M & 60 & 1 & Maxilla & Unilocular & Yes & No \\
\hline Nam et al./2010 & M & 67 & 1 & Mandible & Multilocular & Yes & No \\
\hline $\begin{array}{l}\text { de Andrade Santos } \\
\text { et al. } / 2010\end{array}$ & $\begin{array}{l}3 \mathrm{~F} \\
7 \mathrm{M}\end{array}$ & 59.8 & 10 & $\begin{array}{l}2 \text { maxilla } \\
8 \text { mandible }\end{array}$ & $\begin{array}{l}3 \text { unilocular } \\
6 \text { multilocular } \\
1 \text { N/A } \\
\end{array}$ & Yes & $\begin{array}{l}4 \text { yes } \\
6 \text { no }\end{array}$ \\
\hline Farina et al./2010 & $\mathrm{F}$ & 64 & 1 & Mandible & Multilocular & Yes & No \\
\hline Mori et al./2011 & $\mathrm{F}$ & 59 & 1 & Mandible & Multilocular & N/A & N/A \\
\hline Cohen et al./2011 & $\mathrm{F}$ & 45 & 1 & Mandible & Multilocular & N/A & N/A \\
\hline Selvamani et al./2012 & $\mathrm{M}$ & N/A & 1 & Maxilla & N/A & N/A & N/A \\
\hline Arora et al./2012 & $\mathrm{F}$ & 20 & 1 & Mandible & Unilocular & Yes & No \\
\hline Present case & M & 44 & 1 & Mandible & Unilocular & Yes & No \\
\hline Total & $\begin{array}{l}46 \mathrm{~F} \\
40 \mathrm{M} \\
2 \mathrm{~N} / \mathrm{A} \\
\end{array}$ & 50.24 & 88 & \begin{tabular}{|l}
70 mandible \\
14 maxilla \\
4 N/A \\
\end{tabular} & $\begin{array}{l}31 \text { multilocular } \\
33 \text { unilocular } \\
24 \text { N/A }\end{array}$ & $\begin{array}{l}53 \text { yes } \\
25 \text { no } \\
10 \text { N/A } \\
\end{array}$ & $\begin{array}{l}16 \text { yes } \\
37 \text { no } \\
35 \text { N/A } \\
\end{array}$ \\
\hline
\end{tabular}

$\mathrm{M}=$ male $; \mathrm{F}=$ female $\mathrm{N} / \mathrm{A}=$ not available

noted in $33(51.6 \%)$ cases and multilocular radiolucencies in $31(48.4 \%)$ cases.

Differential diagnosis of radiolucencies within the jaws can include many different conditions. Most common are various types of odontogenic cysts such as radicular and follicular cysts. In the analysis of mandibular radiolucencies, clinical entities such as ameloblastoma and keratocystic odontogenic tumor must be considered since they are usually found in lower jaw, especially in the posterior part of the mandible. Central giant cell granuloma can also occur in the mandible, usually in the anterior portions of the mandible, but cases of central giant cell granuloma have also been described in the posterior portions of the mandible. Other clinical entities such as ameloblastic fibroma, odontogenic myxoma, intraosseous mucoepidermoid carcinoma and central odontogenic fibroma must be considered although they occur less frequently ${ }^{20}$. While clinical and radiological findings are nonspecific, biopsy and histopathologic analysis are needed to reach definitive diagnosis ${ }^{6}$.

\section{Conclusion}

It is concluded that BOCs are a rare type of odontogenic cyst that are usually described in the literature as a multicystic variant of LPC. Radiographic appearance is nonspecific and can be multilocular or unilocular; therefore, histopathologic verification is necessary. In comparison to maxilla, mandible is predominantly affected with $83.3 \%$ of cases. According to our results, the recurrence rate is relatively high (30.1\%), thus necessitating long term follow up. 


\section{References}

1. Weathers DR, Waldron CA. Unusual multilocular cysts of the jaws (botryoid odontogenic cysts). Oral Surg Oral Med Oral Pathol. 1973;36:235-41. doi: 10.4103/0976-237X.103629

2. Van der Waal I. Lateral periodontal cystlike lesion - a discussion on the so-called botryoid odontogenic cyst. J Dent Assoc S Afr. 1992;47:231-3.

3. Carter LC, Carney YL, Perez-Pudlewski D. Lateral periodontal cyst. Multifactorial analysis of a previously unreported series. Oral Surg Oral Med Oral Pathol Oral Radiol Endod. 1996;81:210-6.

4. Hethcox JM, Mackey SA, Fowler CB, Kirkpatrick TC, Deas DE. Case report: diagnosis and treatment of a botryoid odontogenic cyst found in the maxillary anterior region. J Endod. 2010;36:751-4. doi: 10.1016/j.joen.2010.01.013

5. Neville BW. Oral and Maxillofacial Pathology. $2^{\text {nd }}$ ed. Philadelphia(PA): Saunders; 2002.

6. Chi A, Neville B, Klinger B. A multilocular radiolucency.J Am Dent Assoc.2007;138:1102-3.doi: http://dx.doi.org/10.14219/ jada.archive.2007.0323

7. Rasmusson LG, Magnusson BC, Borrman H. The lateral periodontal cyst. A histopathological and radiographic study of 32 cases. Br J Oral Maxillofac Surg. 1991;29:54-7.

8. Üçok Ö, Günhan Ö, Üçok C, Dogan N, Baykul T. Botryoid odontogenic cyst: report of a case with extensive epithelial proliferation. Int J Oral Maxillofac Surg. 2005;34:693-5. doi: http://dx.doi.org/10.1016/j.ijom.2005.01.005

9. Chbicheb S, Bennani A, Taleb B, Wady WE. Botryoid odontogenic cyst. Rev Stomatol Chir Maxillofac. 2008;109:114-6. doi: 10.1016/j.stomax.2007.12.004

10. Standish SM, Shafer WG. The lateral periodontal cyst. J Periodontol. 1958;29:27-33.
11. Holder TD, Kunkel PW. Case report of a periodontal cyst. Oral Surg Oral Med Oral Pathol. 1958;11:150-4.

12. Siponen M, Neville BW, Damm DD, Allen CM. Multifocal lateral periodontal cysts: a report of 4 cases and review of the literature. Oral Surg Oral Med Oral Pathol Oral Radiol Endod. 2011;111:225-33. doi: 10.1016/j.tripleo.2010.09.072

13. Altini M, Shear M. The lateral periodontal cyst: an update. J Oral PatholMed. 1992;21:245-50.

14. Méndez P, Junquera L, Gallego L, Baladrón J. Botryoid odontogenic cyst: clinical and pathological analysis in relation to recurrence. Med Oral Patol Oral Cir Bucal. 2007;12:594-8.

15. Ramer M, Valauri D. Multicystic lateral periodontal cyst and botryoid odontogenic cyst: multifactorial analysis of previously unreported series and review of literature. N Y State Dent J. 2005;71:47-51.

16. De Sousa SO, Campos AC, Santiago JL, Jaeger RG, de Araujo VC. Botryoid odontogenic cyst: report of a case with clinical and histogenetic considerations. Br J Oral Maxillofac Surg. 1990;28:275-6. doi: http://dx.doi.org/10.1016/0266-4356(90) 90067-U

17. Cohen D, Bhattacharyya I. Diagnostic discussion. Botryoid odontogenic cyst (BOC). Todays FDA. 2011;23:31-3.

18. Selvamani M, Donoghue M, Basandi PS. Analysis of 153 cases of odontogenic cysts in a South Indian sample population: a retrospective study over a decade. Braz Oral Res. 2012;26:3304. doi: http://dx.doi.org/10.1590/S1806-83242012005000007

19. Arora P, Bishen KA, Gupta N, Jamdade A, Kumar. GR. Botryoid odontogenic cyst developing from lateral periodontal cyst: a rare case and review on pathogenesis. Contemp Clin Dent. 2012;3:326-9. doi: 10.4103/0976-237X.103629.

20. White SC, Pharoah MJ. Oral Radiology: Principles and Interpretation. $6^{\text {th }}$ edn. St Louis (MO): Mosby; 2009.

Sažetak

\section{BOTRIOIDNA CISTA - RIJEDAK TIP ODONTOGENE CISTE: PRIKAZ SLUČAJA I PREGLED LITERATURE}

\section{B. Vidaković, I. Uljanić, J. Grgurević, B. Perić i S. Manojlović}

Botrioidna cista je rijedak tip odontogene ciste koja se uobičajeno smatra multilokularnom varijantom lateralne periodontne ciste. Prvi put je opisana 1973. godine, a do danas je u literaturi opisano manje od sto slučajeva. Botrioidne ciste su obilježene multilokularnim histološkim nalazom i većom učestalošću recidiva u odnosu na lateralne periodontne ciste. U ovom članku prikazujemo slučaj iz naše kliničke prakse. Rad je popraćen pregledom literature prethodnih slučajeva dosad opisanih u literaturi. Rezultati su pokazali da botrioidne ciste uglavnom zahvaćaju populaciju u pedesetim godinama života, s malo većom učestalošću kod žena (53,5\%) u odnosu na muškarce (46,5\%). Donja čeljust je najčešće zahvaćena regija sa 70 $(83,3 \%)$ slučajeva. Gornja čeljust je povremeno zahvaćena s učestalošću od 14 (16,7\%) slučajeva. Radiografski prikaz botrioidne ciste može biti multilokularan ili unilokularan. Zaključno može se utvrditi da je učestalost recidiva velika $(30,1 \%)$ pa je potrebno dugotrajno praćenje.

Ključne riječi: Odontogene ciste - dijagnostika; Odontogene ciste - patologija; Dijagnostika, diferencijalna; Mandibularne bolesti - dijagnostika; Mandibularne bolesti-patologija; Prikazi slučaja 